ఠ

\title{
The Short Physical Performance Battery is a discriminative tool for identifying patients with COPD at risk of disability [Corrigendum]
}

Bernabeu-Mora R, Medina-Mirapeix F, LlamazaresHerrán E, et al. Int J Chron Obstruct Pulmon Dis. 2015;10: 2619-2626.

Page 2626, Acknowledgments section, the text "The authors wish to thank the patients and personnel of the hospital unit for their cooperation during the course of this study. The study was supported by medical manager of AstraZeneca Pharmaceutical Spain, S.A. and Maite Pérez." Should read "The authors wish to thank the patients and personnel of the hospital unit for their cooperation during the course of this study. The study was supported by medical manager AstraZeneca Pharmaceutical Spain, S.A. Maite Pérez, Pfizer and Menarini."

\section{Publish your work in this journal}

The International Journal of COPD is an international, peer-reviewed journal of therapeutics and pharmacology focusing on concise rapid reporting of clinical studies and reviews in COPD. Special focus is given to the pathophysiological processes underlying the disease, intervention programs, patient focused education, and self management protocols.

\section{Dovepress}

This journal is indexed on PubMed Central, MedLine and CAS. The manuscript management system is completely online and includes a very quick and fair peer-review system, which is all easy to use. Visit http://www.dovepress.com/testimonials.php to read real quotes from published authors. 